\title{
UPDATE ON EMERALDS FROM THE SANDAWANA Mines, ZimbabWE
}

\author{
By J. C. (Hanco) Zwaan, Jan Kanis, and Eckehard J. Petsch
}

\begin{abstract}
Zimbabwe's Sandawana mines have been an important producer of emeralds for 40 years. Since the mines came under new ownership in 1993, consistent production has been established and, in addition to the small sizes for which Sandawana is known, greater numbers of polished stones as large as $1.50 \mathrm{ct}$ have been produced. Currently, mining at the most active area, the Zeus mine, is done underground, with the ore processed in a standard washing/ screening trommel plant. Sandawana emeralds can be readily separated from emeralds from other localities. They have high refractive indices and specific gravities. Two amphiboles, actinolite and cummingtonite, are abundant inclusions; albite and apatite are common. Also found are remnants of fluid inclusions. Chemically, Sandawana emeralds typically have a very high chromium content.
\end{abstract}

\begin{abstract}
T $\mathrm{t}$ is believed by some that the area now known as Zimbabwe was the fabled land of Ophir, which produced gold for King Solomon's temple. By the middle of the 10th century, the discovery of ancient gold workings in different parts of the country had led Arab geographers to speculate on Ophir in their writings (Summers, 1969). Although gold, and even diamonds, stimulated exploration in the 20th century, for gemologists the most important discovery was the large emerald deposit found in the mid1950s at the area called Sandawana. For four decades, Sandawana has provided the jewelry industry with large quantities of fine, if typically small, emeralds (figure 1). Production was sporadic for much of this period, but new ownership in the mid-1990s has brought renewed attention to exploration and mining, with excellent results in terms of both the quantity and quality of the stones produced.

Although the Sandawana mines have been known for some time now, only short articles on the characteristics of Sandawana emeralds have been published to date. There has been little information about the mining area and the techniques used for exploration, mining, and processing. This article attempts to fill that gap. Not only does it provide some results of a detailed study on the geologic factors that contributed to emerald formation in this part of Zimbabwe, but it also offers new data on the distinctive properties of these emeralds.
\end{abstract}

\section{HISTORICAL BACKGROUND}

In 1868, German geologist Carl Mauch uncovered some of the ancient gold workings to which Arab geographers had referred-in the interior of what is now Zimbabwe, near Hartley (now Chegutu). Subsequently, after Cecil Rhodes's British South Africa Company obtained a charter to promote commerce and colonization in Zimbabwe in 1889, prospecting for gold became a major industry. The simplest surface indicator was an ancient working. In the nine years between 1890 and the outbreak of the South African Boer 
Figure 1. The Sandawana mines are known for the small but fine emeralds that have been produced there for more than 40 years. This 16-strand necklace is composed entirely of Sandawana emeralds, more than 1,000 beads, which range from 4 to $7 \mathrm{~mm}$ in diameter. Courtesy of Fine Emerald, Inc., New York City; photo (C Harold «) Erica Van Pelt.

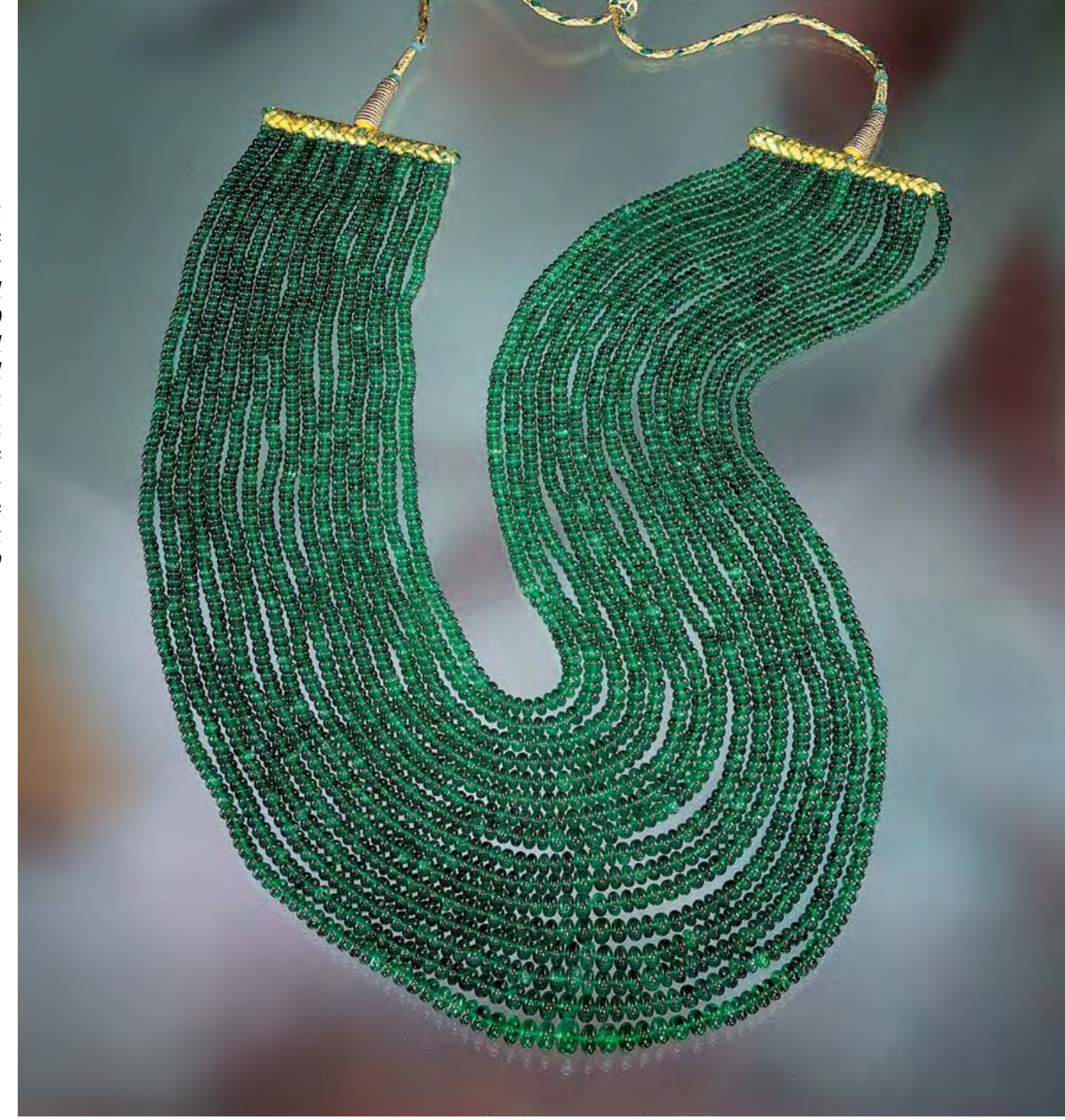

War in 1899, over 100,000 gold claims were pegged (Summers, 1969).

The search for gems in Zimbabwe appears to be more recent and can be dated only from $\mathrm{H}$. R. Moir's 1903 diamond find in the Somabula Forest (Mennell, 1906). Some prospecting and minor mining for diamonds took place between 1905 and 1908, but these efforts faded as the results did not meet the expenses. Subsequently, several workers tried to make their fortunes in small mining operations, but interest waned and activity all but ceased (Wagner, 1914).

In 1923, Zimbabwe became a British colony under the name Southern Rhodesia. A sudden change in the fortunes of the nation's gemstone industry arrived in the mid-1950s, as a result of increased demand for beryllium and lithium minerals. On October 7, 1956, the first emerald was found in the Belingwe district (now Mberengwa) by Laurence Contat and Cornelius Oosthuizen, two former civil servants who had relinquished their posts to take up full-time prospecting. This first stone was recovered in the Mweza Hills about $5 \mathrm{~km}$ west-southwest of the confluence of the Nuanetsi (now Mwenezi) and Mutsime Rivers. They called their first claim "Vulcan" (Martin, 1962).

On May 17, 1957, after a rainstorm, a Vulcan worker named Chivaro found a deep green crystal protruding from a muddy footpath, some $2.5 \mathrm{~km}$ northeast of what eventually became the Vulcan mine. He reported the find to his employers, who rewarded him handsomely. Follow-up at the spot, which would later become known as the Zeus mine, revealed the presence of more such crystals in the "black cotton" soil, the popular name for a dark calcareous soil, relatively high in montmorillonitic 
Limpopo rivers. In the south and southeast of the country are the extensive Limpopo and Save basins, which form part of the Low Veld land below 3,000 feet $(915 \mathrm{~m})$.

The Sandawana mines are located in the Low Veld (coordinates roughly $20^{\circ} 55^{\prime} \mathrm{S}$ and $29^{\circ} 56^{\prime} \mathrm{E}$, confirmed by global positioning satellite [GPS] readings), approximately $830 \mathrm{~m}$ above sea level. The temperature ranges from a high of $41^{\circ} \mathrm{C}$ in the summer (November) and a low of $6^{\circ} \mathrm{C}$ in the winter (May). The area has an average summer rainfall of $700 \mathrm{~mm}$, with occasional light drizzle in winter. The natural vegetation is open savanna (Böhmke 1982).

Zimbabwe has a well-maintained road system, and the nearest villages to the Sandawana minesMberengwa and West Nicholson-can be reached from Masvingo, Gweru, or Bulawayo on good tarred roads (again, see figure 2). The exception is the last $65 \mathrm{~km}$ traveling via Mberengwa (or $68 \mathrm{~km}$ coming via West Nicholson), which are on gravel roads that, during the winter rainy season, are best traversed using a four-wheel-drive vehicle. When the weather conditions are good, however, the easiest way to reach the Sandawana area is by a small plane, as there is a good landing strip at the Zeus mine. The mine can be visited by invitation only.

The Sandawana mines have their own medical clinic, which is essential in this remote area, and a primary school. There is also a sports-clubhouse, a soccer club, a community hall, a general store, as well as regular bus service to the capital, Harare.

The mining lease and claim holdings cover a $21-\mathrm{km}$-long strip along the southern slope of the Mweza Hills. They are bordered on the north by the densely populated Communal Lands. On their southern flank, the Sandawana claims share a $16 \mathrm{~km}$-long electrified game fence with "The Bubiana Conservancy." This syndicate of seven different ranches, which covers an area of 350,000 acres, represents one of the largest private game reserves in the world and is supported by the World Wildlife Fund.
Figure 3. This simplified geologic map shows the location of both the currently producing emerald mines and the old emerald mines in the Mweza greenstone belt, near the major shear zone between the Zimbabwe craton and the Limpopo mobile belt. This map is mainly based on data from Robertson (1973) and Mkweli et al. (1995), and from satellite images.

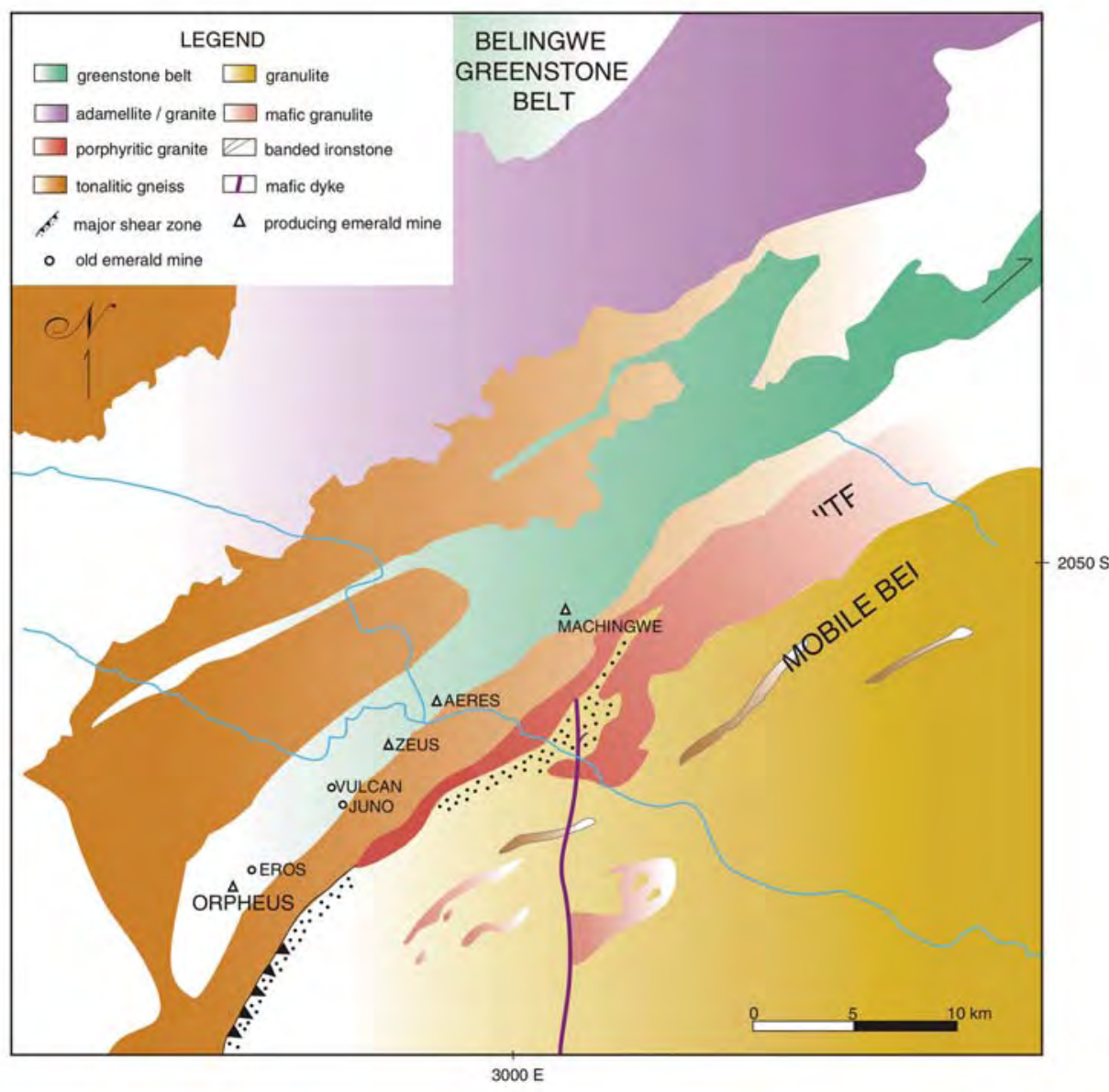




\section{GEOLOGY AND OCCURRENCE}

The Zimbabwe craton (a relatively stable part of the Earth's continental crust) covers a large part of Zimbabwe and consists of Archean greenstone belts and granite terrains. The greenstone belts are important producers of gold, but they also contain significant amounts of chromium and nickel. The Great Dike, $530 \mathrm{~km}$ long and up to $4 \mathrm{~km}$ wide, crosses the Zimbabwe craton from north to south and is a major source of chromium.

There are few early papers on the geology of the Sandawana region (Worst, 1956; Gübelin, 1958; Böhmke, 1966), but geologic research in this area has intensified recently, as evidenced by the detailed studies on nearby greenstone belts (e.g., Fedo et al., 1995; Fedo and Eriksson, 1996) and the adjacent Limpopo mobile belt (e.g., Rollinson and Blenkinsop, 1995; Mkweli et al., 1995).

These studies underline the important magmatic and tectonic processes in the area, which resulted in the emplacement of emeralds there, and include new data on the timing of these events. In addition, the petrologic and mineralogic aspects of the complex Sandawana occurrence will be published in the near future (J. C. Zwaan, in prep.). Such publications ultimately are possible because of the open attitude of Sandawana Mines (Pvt.) Ltd.

The Sandawana emerald deposits lie along the southern limb of the Mweza greenstone belt, which is located at the southern margin of the Archean Zimbabwe craton, close to the northern margin of the Limpopo mobile belt (again, see figure 3). The Mweza greenstone belt consists of a series of intensely deformed and moderately metamorphosed ultramafic-to-mafic volcanic rocks and metasediments. It also contains numerous relatively small pegmatite bodies that tend to be concentrated at the southern end of the belt. Emeralds occur near the pegmatites at the contact with (ultra)mafic lavas; they are concentrated in pockets at sites where the pegmatite is tightly folded and/or the rocks are sheared. These "ideal" locations are characterized by actinolite schist streaks in the pegmatite and pegmatitic stringers in the adjacent actinolite schist (figure 4).

An order of geologic events in the Sandawana region has been reconstructed from field evidence and geochronological data (Robertson, 1973; Rollinson and Blenkinsop, 1995; Mkweli et al., 1995; Fedo and Eriksson, 1996). About 2.6 billion years ago, the Northern marginal zone was uplifted over the Zimbabwe craton, accompanied by thrusting in a north-northwest direction. Associated with this at the southern border of the Mweza greenstone belt was a series of shear zones (planar zones of relatively intense deformation, resulting in crushing and brecciation or ductile deformation of the rock; such areas are often mineralized by ore-forming solutions). In response to the uplift and thrusting, crustal shortening occurred, which caused folding and metamorphism of the greenstone belt. The old greenstones consist of ultramafic lavas, which are

Figure 4. At Sandawana, emeralds are typically found in the zone (outlined in red here) at the contact of small pegmatite bodies and greenstone (left, in the Zeus mine, 25/28 stope, 200 foot [ $61 \mathrm{~m}$ ] level). Schlieren (streaks) of actinolite and phlogopite in pegmatite are commonly seen in the "ideal" emerald-bearing pegmatite bodies (right, in the Zeus mine, 17/16 stope, 250 foot [76 m] level). Photos by J. C. Zwaan.
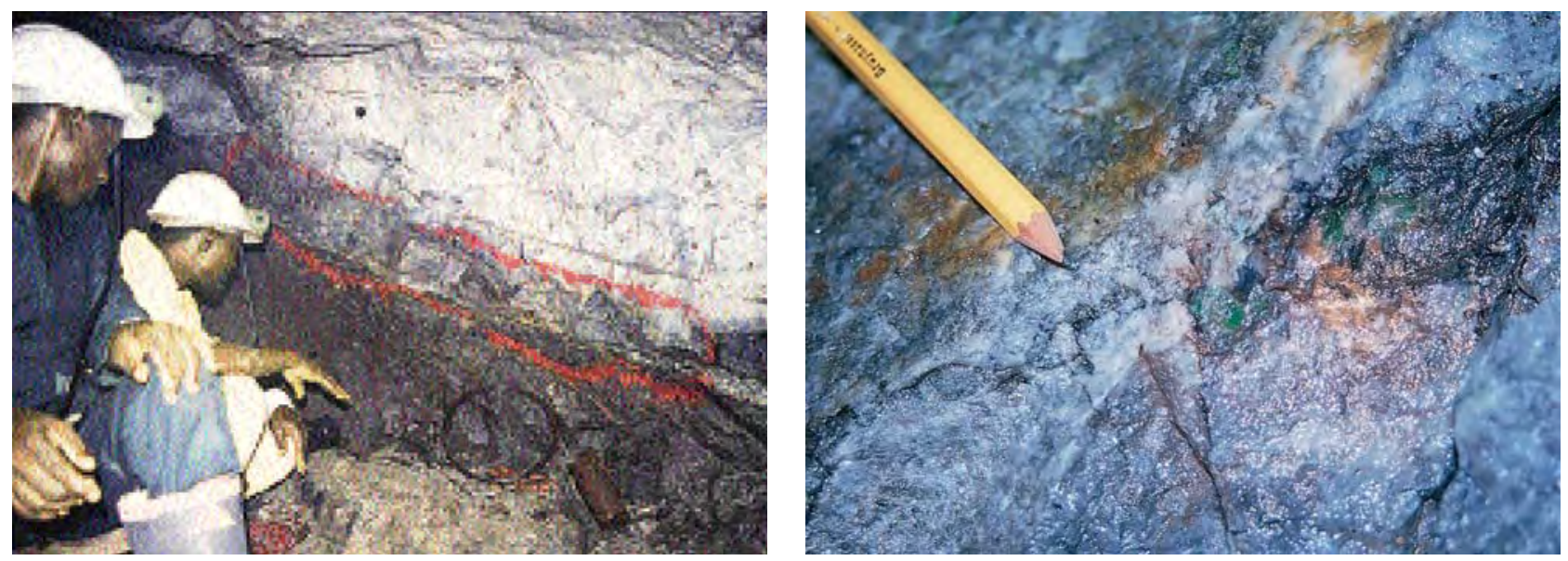


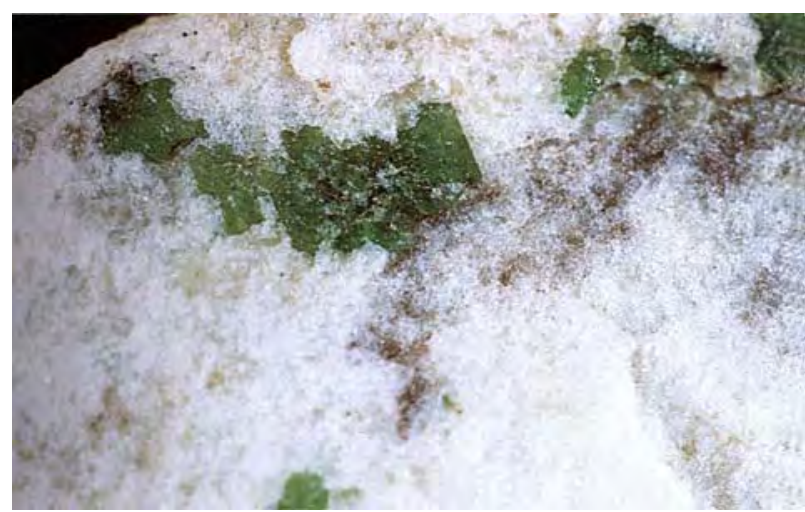

Figure 11. Most of the emeralds seen in situ (here, in fine-grained, sugary albite) have been either euhedral or subhedral, with prominent prismatic faces. Photo (C) NNM, The Netherlands.

matite, all from the Zeus mine, and one mediumgreen emerald from the Orpheus mine; 23 were performed on amphibole inclusions; and 20 analyses were done on other inclusions.

Both the Raman and microprobe analyses were performed at the Institute of Earth Sciences, Free University of Amsterdam.

Visual Appearance. Fashioned Sandawana emeralds are known for their attractive color. Most of the samples we examined were a vivid green with medium to dark tones (figure 14). It is striking that the darker tones are not restricted to the larger stones; for instance, one stone weighing only $0.10 \mathrm{ct}$ had a medium dark tone. Sandawana emeralds typically show even color distribution and are slightly to heavily included. Eye-visible internal features such as minerals or (partially healed) fractures are quite common.

Physical Properties. The standard gemological properties of the Sandawana emeralds tested are given in table 1 and discussed below.

Refractive Indices. The measured values fell within a somewhat narrower range than was indicated by Gübelin $\left(1958 ; \mathrm{n}_{\varepsilon}=1.581-1.588\right.$ and $\mathrm{n}_{\omega}=1.588-$ $1.595)$, which only confirms that small variations exist. More than $70 \%$ of the stones tested showed $\mathrm{n}_{\varepsilon}=1.585-1.586$ and $\mathrm{n}_{\omega}=1.592-1.593$, and $90 \%$ showed a birefringence of 0.007 .

Specific Gravity. The measured values varied between 2.73 and 2.80. However, stones weighing 0.15 ct or more gave results between 2.74 and 2.77, and most stones (66\%) showed values around
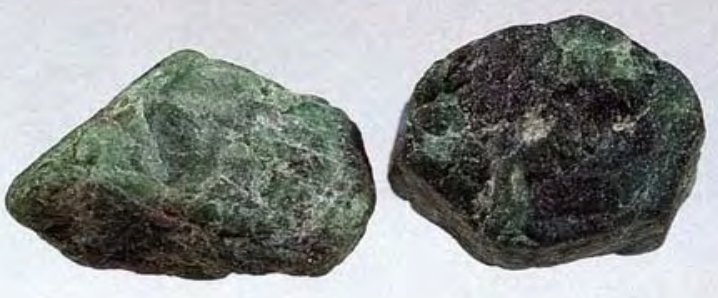

Figure 12. Note the crystal habits of these large emerald crystals found at the Orpheus mine, $103.58 \mathrm{ct}$ (left) and $64.95 \mathrm{ct}$ (right). Both have translucent areas from which cabochons or beads could be cut. Photo (C) NNM,

The Netherlands.

Figure 13. Although the row of calibrated emeralds $(0.09-0.18 \mathrm{ct})$ is more typical of the emeralds routinely produced from the Sandawana mines, more larger stones, such as the approximately 0.80 ct pear shape, have been produced recently. Stones like the $3.67 \mathrm{ct}$ Sandawana emerald in the ring are still extremely rare. The row of calibrated emeralds is courtesy of Edward Boehm, Joeb Enterprises, Atlanta, Georgia; the ring and pear-shaped emerald are courtesy of The Collector Fine Jewelry, Fallbrook and La Jolla, California. Photo (C) Harold et Erica Van Pelt.

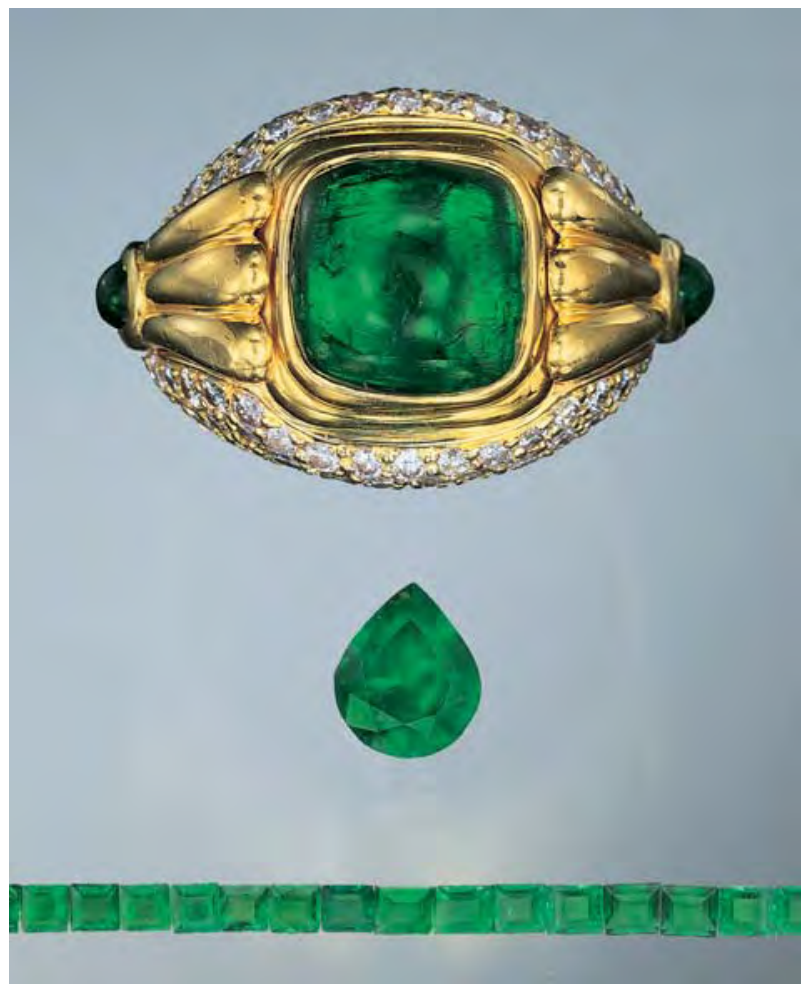




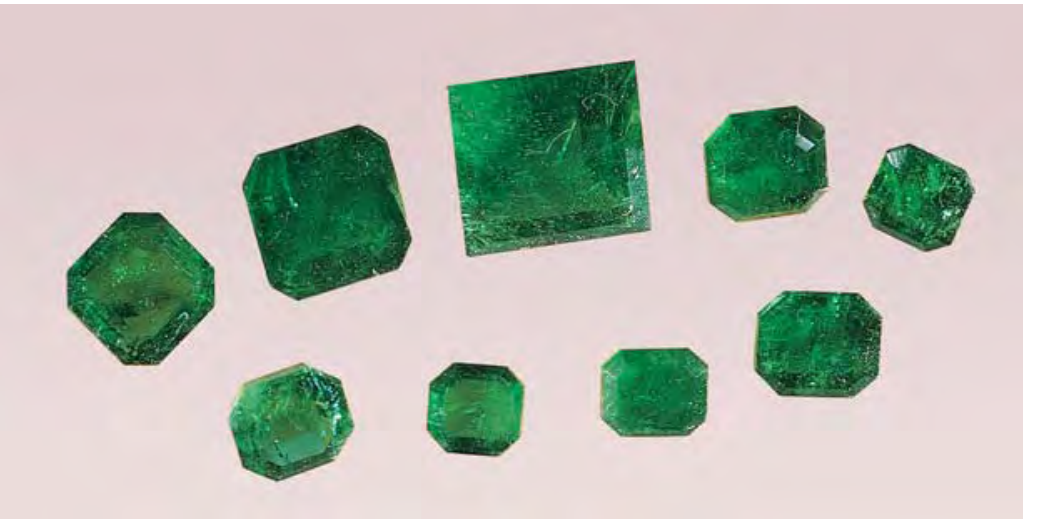

Figure 14. These stones, which range from 0.28 to $1.87 \mathrm{ct}$, are part of the group of $36 \mathrm{cut}$ Sandawana emeralds examined for this study. Like most of the polished samples studied, they are medium to dark in tone. Photo (C) NNM, The Netherlands.

2.75-2.76. These numbers are consistent with earlier reports by Gübelin (1958) and Böhmke (1966). Note that the smaller stones with higher specific gravities contained many (predominantly amphibole) inclusions. Thus, the scattering of values between 2.73 and 2.80 can be attributed in part to

TABLE 1. Physical properties of 36 cut emeralds from Sandawana, Zimbabwe.

\begin{tabular}{|c|c|}
\hline Color & $\begin{array}{l}\text { Saturated colors ranging from medium to dark } \\
\text { green. Color is evenly distributed; only weak } \\
\text { color zoning is seen in some crystals and pol- } \\
\text { ished stones. }\end{array}$ \\
\hline Clarity & Slightly to heavily included \\
\hline Refractive indices & $\mathrm{n}_{\varepsilon}=1.584-1.587, \mathrm{n}_{\omega}=1.590-1.594$ \\
\hline Birefringence & $0.006-0.007$ \\
\hline Optic character & Uniaxial negative \\
\hline $\begin{array}{l}\text { Specific gravity } \\
\text { (samples } 0.15 \mathrm{ct} \text { ) }\end{array}$ & $2.74-2.77$ \\
\hline Pleochroism & $\begin{array}{l}\text { Dichroism: yellowish green }(\omega) \text { and bluish } \\
\text { green }(\varepsilon)\end{array}$ \\
\hline Fluorescence & $\begin{array}{l}\text { Usually inert to long- and short-wave ultraviolet } \\
\text { radiation. Sometimes faint green to long-wave } \\
\text { UV. }\end{array}$ \\
\hline $\begin{array}{l}\text { Reaction to } \\
\text { Chelsea filter }\end{array}$ & $\begin{array}{l}\text { Light pink to pinkish red; the majority of the } \\
\text { material shows pink }\end{array}$ \\
\hline Internal features & $\begin{array}{l}\text { - Mineral inclusions: actinolite and cumming- } \\
\text { tonite needles and long-prismatic laths, ran- } \\
\text { domly oriented; albite and apatite, both } \\
\text { showing various morphologies; phlogopite, } \\
\text { calcite, dolomite, quartz, ilmenorutile } \\
\text { - Partially healed fissures } \\
\text { - Decrepitated primary fluid inclusions, typically } \\
\text { rectangular in shape } \\
\text { - Weak, if any, color zoning; complex zoning } \\
\text { roughly parallel to the prismatic crystal faces } \\
\text { seen in some clean crystals }\end{array}$ \\
\hline
\end{tabular}

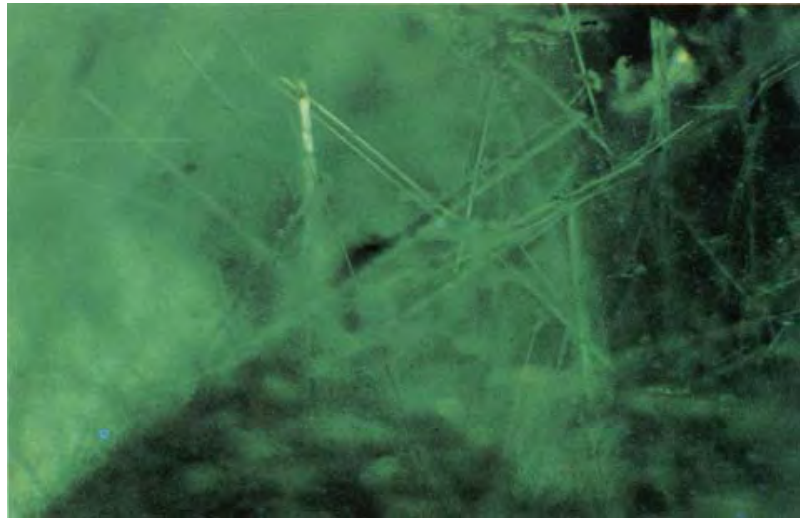

Figure 15. The "tremolite" needles and laths that are a well-known hallmark of emeralds from Sandawana were conclusively identified as actinolite and cummingtonite. Darkfield illumination, magnified 50x; photomicrograph by J. C. Zwaan.

inaccuracy due to the small size of the stones and the greater influence of the inclusions at these sizes.

Internal Features. Mineral Inclusions. The most abundant inclusions in the Sandawana emeralds examined are fibrous amphibole crystals (figure 15), which were previously described by various authors (e.g., Gübelin, 1958; Böhmke, 1982) as tremolite needles or fibers. In this study, we identified two amphiboles. Actinolite (a series with tremolite and ferro-actinolite) was identified by optical microscopy with transmitted light and by electron microprobe analyses. Tremolite and actinolite have the same basic chemical formula, $\mathrm{Ca}^{2}\left(\mathrm{Mg}_{1} \mathrm{Fe}^{2+}\right)_{5-}$ $\mathrm{Si}_{8} \mathrm{O}_{22}(\mathrm{OH})_{2}$, but they have different $\mathrm{Mg} /\left(\mathrm{Mg}+\mathrm{Fe}^{2+}\right)$ ratios. Tremolite contains very little iron and is extremely rich in magnesium $\left(\mathrm{Mg} /\left(\mathrm{Mg}+\mathrm{Fe}^{2+}\right)=\right.$ 1.0-0.9). Actinolite, however, contains significantly more iron $\left(\mathrm{Mg} /\left[\mathrm{Mg}+\mathrm{Fe}^{2+}\right]=0.50-0.89\right.$; e.g., Leake, 1978; Fleischer and Mandarino, 1995). The analyses gave a $\mathrm{Mg} /\left(\mathrm{Mg}+\mathrm{Fe}^{2+}\right)$ ratio of $0.69-0.74$, which is well within the actinolite field.

The other amphibole, identified with these same techniques, is cummingtonite, which occurs both as fibers and as somewhat thicker prismatic crystals. It is as abundant as actinolite and sometimes (where the fibers are large and thick) can be distinguished from it by its slightly higher relief in transmitted light and the presence of lamellar twinning in polarized light (figure 16).

Using the electron microprobe, we observed that the thicker actinolite crystals are zoned and often show a rim of cummingtonite; in contrast, the cummingtonite crystals are not zoned. In many thinner amphibole needles, actinolite is intergrown 

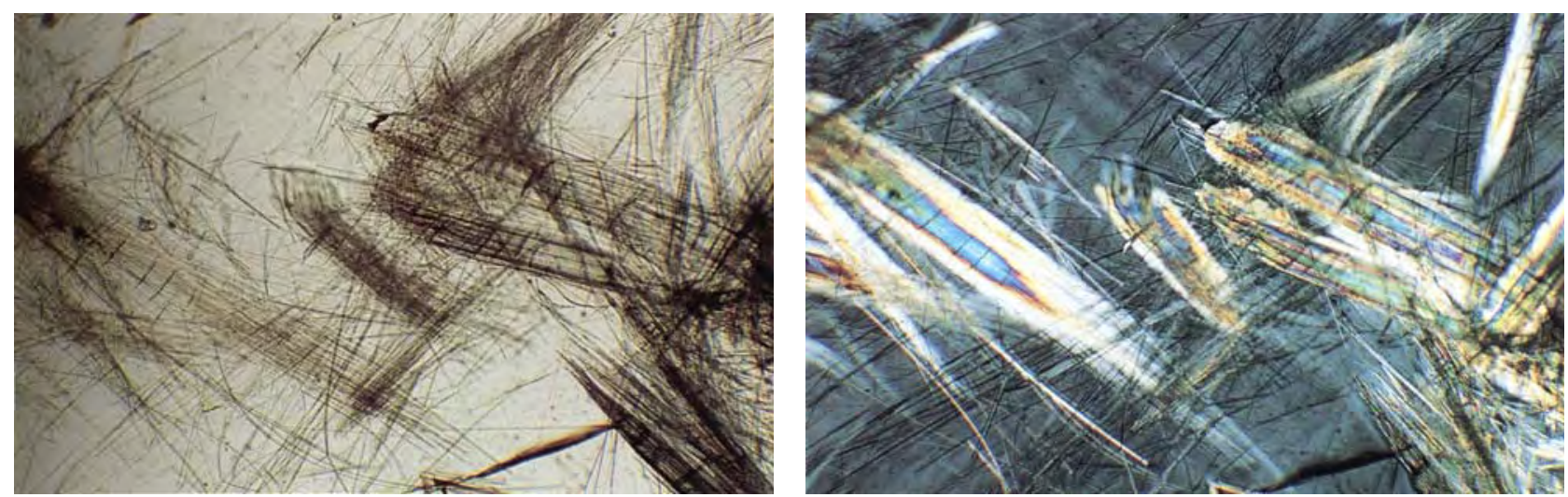

Figure 16. Long-prismatic crystals of the amphiboles actinolite and cummingtonite were identified in the Sandawana emeralds studied. In transmitted light (left), the cummingtonite laths (here, on the right of the photomicrograph) show a slightly higher relief. Between crossed polarizing filters (right), these same cummingtonite laths show lamellar twinning. Photomicrographs by J. C. Zwaan; magnified 35x.

with cummingtonite. Therefore, it will not come as a surprise that it is virtually impossible to distinguish between actinolite and cummingtonite with a normal gemological microscope, using either transmitted or darkfield illumination.

Another fairly common mineral inclusion is albite. It most frequently occurs as large tabular fragments (figure 17) or as small, slightly rounded, colorless crystals (figure 18). It also occurs in the form of a whitish, rectangular crystal surrounded by minute grains of (probably) albite, which give it the appearance of a snowball (figure 19).

Apatite is a common inclusion, too, but the apatite crystals are often very small and show various morphologies. Apatite may occur in clusters of small colorless-to-light green crystals, or as isolated,

Figure 17. Large colorless to milky white tabular albite crystals, such as the one shown here near the surface of the stone, frequently occur in Sandawana emeralds. Oblique illumination, magnified 60x; photomicrograph by J. C. Zwaan.

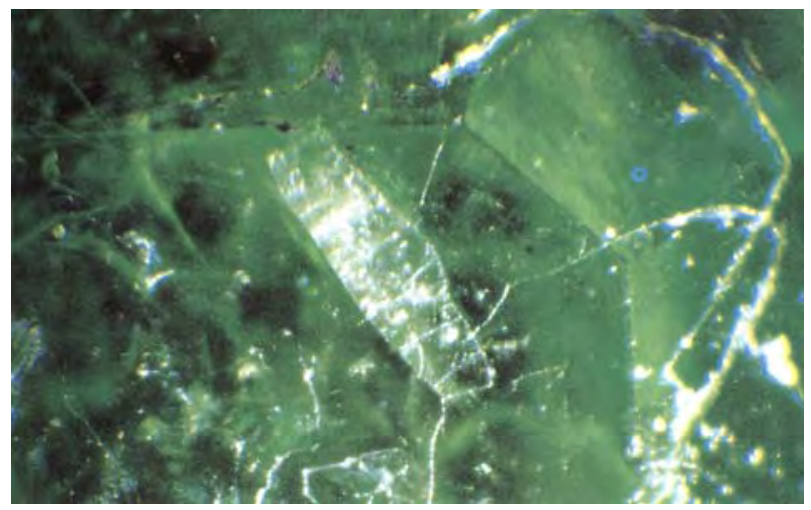

idiomorphic crystals, sometimes brownish green but also colorless (figure 20). In addition, apatite frequently occurs as rounded crystals with an irregular surface (figure 21). This illustrates that, in some gem materials, the same mineral can have a variety of appearances, which makes these inclusions difficult to identify by using only the microscope. In many cases, Raman spectroscopy helped reveal the true nature of an inclusion (see, e.g., Pinet et al., 1992; Hänni et al., 1997); in some, it easily distinguished between albite and apatite, which may look very similar.

Phlogopite is abundant in the ore zone where the emeralds are found, but it was only occasionally present in the samples we studied. The distinctive orangy brown plate-like crystals are easy to identify

Figure 18. Many Sandawana emeralds of various qualities were also seen to contain small, rounded, colorless albite crystals. Transmitted light, magnified 125x; photomicrograph by J. C.

Zwaan.

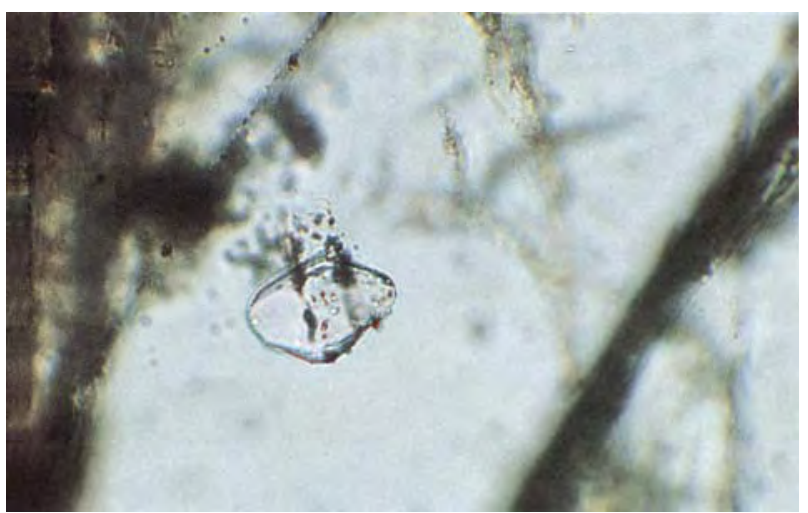




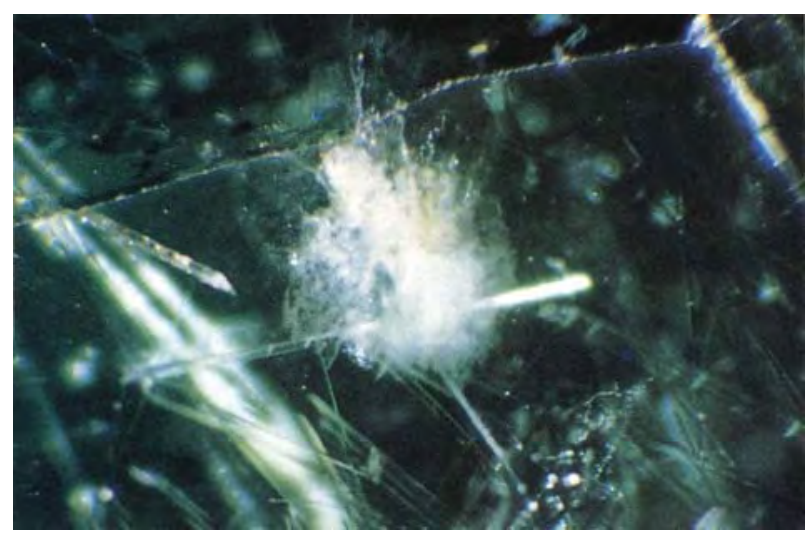

Figure 19. This albite crystal, which is surrounded by minute inclusions (probably also albite), looks like a snowball. Oblique illumination, magnified 60x; photomicrograph by J. C. Zwaan.

visually (figure 22; identification confirmed by microprobe). Inclusions also identified visually (and confirmed by microprobe) were calcite and a dolomite-group carbonate, emerald, quartz (very small, elongated, and rounded crystals), and zircon (minute crystals). Large black crystals of chromiumbearing ilmenorutile were found in one cut emerald, but they cannot be considered common inclusions. Gersdorffite, another opaque mineral, also was identified by microprobe analysis, but it is only present as extremely small grains. In the reaction rim of a medium-green emerald that was found in the pegmatite near a streak of amphibole schist (only 10

Figure 21. In a classic "Sandawana scene" of long actinolite and cummingtonite crystals, lie three small, rounded apatite inclusions with slightly corroded surfaces - very different in appearance from those apatites shown in figure 20. Transmitted light, magnified 160x; photomicrograph by J.C. Zwaan.

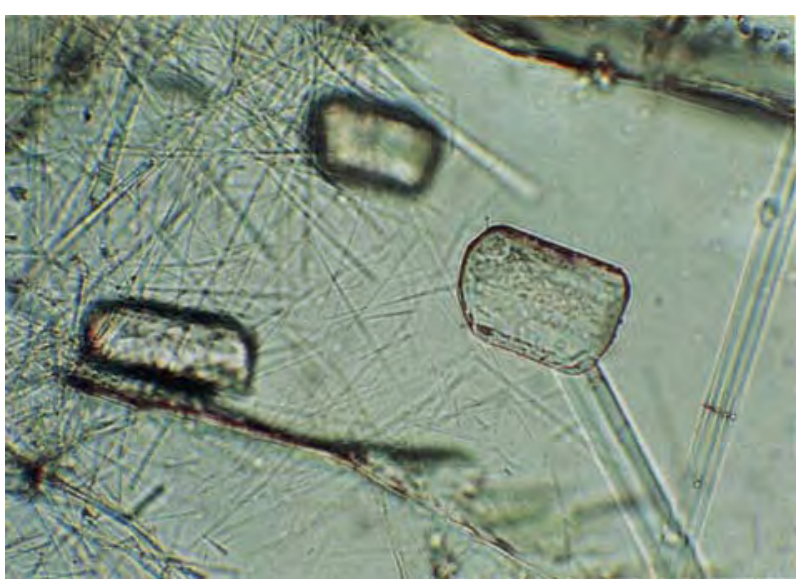

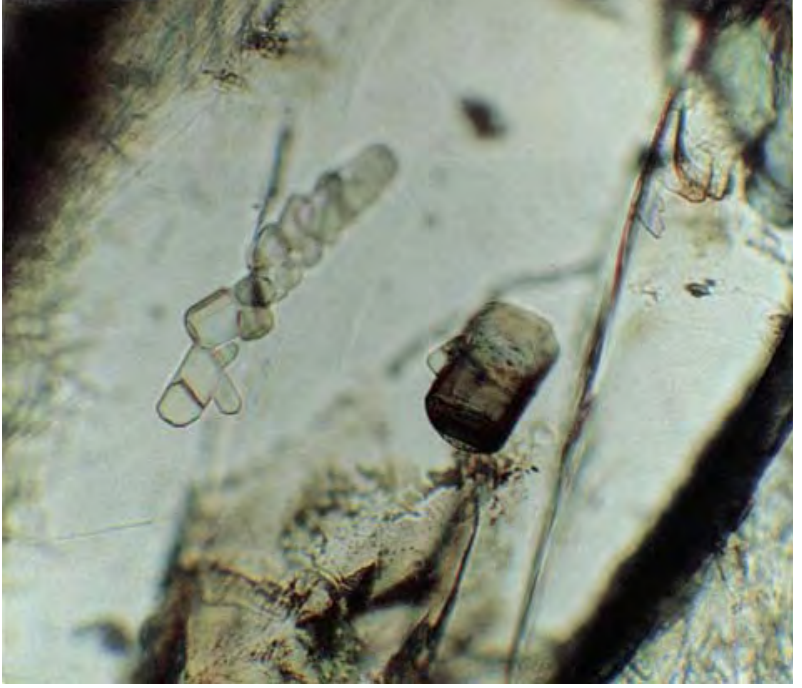

Figure 20. A cluster of small apatite crystals lies near a larger brownish green apatite in this Sandawana emerald. Transmitted light, magnified 100x; photomicrograph by J. C. Zwaan.

$\mathrm{cm}$ away from the contact with the greenschist), the lithium amphibole holmquistite was tentatively identified (from electron microprobe analysis and calculation of the chemical formula) but no cummingtonite or actinolite. This was confirmed by optical microscopy: The amphiboles analyzed showed straight extinction under crossed polarizing filters, which is characteristic for holmquistite. We did not encounter any of the resorbed garnet inclusions that had been previously described (Gübelin, 1958; Gübelin and Koivula, 1992); similar-appearing inclusions (figure 23) were investigated with Raman spectroscopy but could not be identified as garnet

Figure 22. Seen here at the edge of a piece of gem-quality rough, this orangy brown plate-like crystal is phlogopite, which is somewhat rare in Sandawana emeralds. The black inclusion at the lower left was tentatively identified as a metamict zircon. Transmitted light, magnified 100x; photomicrograph by J. C. Zwaan.

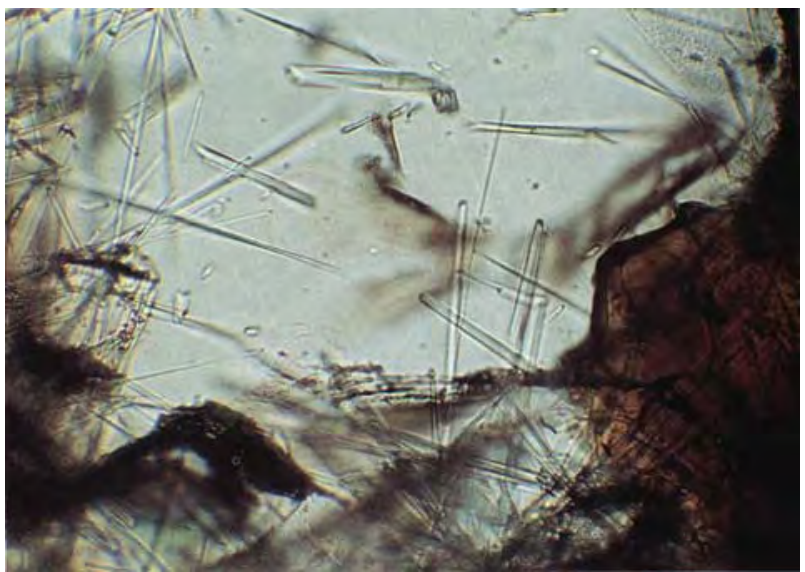




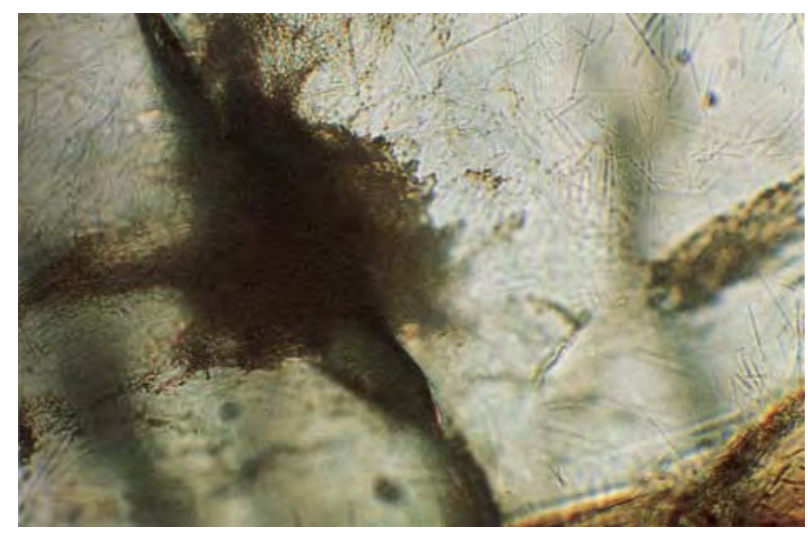

Figure 23. Although similar in appearance to previously described garnet inclusions with brownish haloes, the inclusion shown here is probably a mixture of limonite (on the basis of visual appearance) and amphiboles (as identified by Raman spectroscopy). Garnets were not identified in any of the Sandawana emeralds studied for this report. Transmitted light, magnified 160x; photomicrograph by J. C. Zwaan.

(which should be easily identified by that method; see Pinet et al., 1992).

Fluid Inclusions. Much more difficult to investigate than the solid inclusions, the fluid inclusions seen in the samples we investigated are very different from the well-known brine inclusions present in, for example, Colombian emeralds. In our search for fluid inclusions, we did find partially healed fractures with minute inclusions to be quite common (figure 24). However, most of these inclusions were so small (less than $6 \mu \mathrm{m}$ in diameter) that they could not be analyzed by Raman spectroscopy. Some of the slightly larger inclusions in a partially healed fracture were found to be empty, and quite a few contained minerals that were identified as carbonates (figure 25).

Slightly larger isolated inclusions (approximately $35 \mu \mathrm{m}$ long) were seen to occur as small, dark, comma-like features oriented parallel to the c-axis (figure 26). These inclusions, too, were empty and carbonate has been identified near them. Carbonate is often found near decrepitated inclusions that may have contained $\mathrm{CO}_{2}$ (J. Touret, pers. comm., 1996). These isolated inclusions thus can be interpreted as the remnants of primary $\mathrm{CO}_{2}$ inclusions.

In addition to these partially healed fissures and isolated decrepitated inclusions, straight trails with decrepitated inclusions were also a common feature in the emeralds from Sandawana (figure 27).

Tube-like two-phase, liquid and gas, inclusions were seen in one sample, but they were difficult to

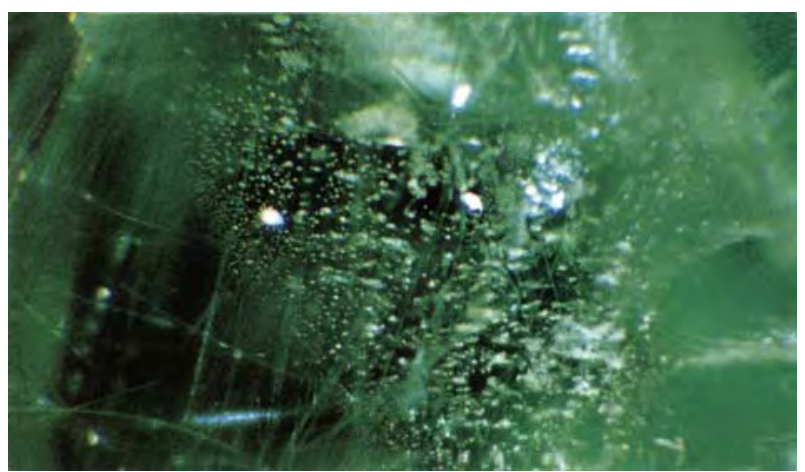

Figure 24. Partially healed fractures containing minute inclusions were often present in the Sandawana emeralds examined. Darkfield illumination, magnified 60x; photomicrograph by J. C. Zwaan.

identify with a standard gemological microscope because there were so few of them and they were extremely small.

Growth Zoning. In most of the samples, the color was evenly distributed. Occasionally, we saw a very weak and broad medium to medium-dark green color zoning, which was straight and parallel to the prismatic crystal faces. Some clean idiomorphic crystals with an even color distribution actually showed complex deformation twinning when viewed with crossed polarizers (figure 28). This pattern, together with anomalous birefringence, indicates considerable directional stress during crystal growth.

Figure 25. A closer look at the minute inclusions in a partially healed fracture reveals that the doubly refractive minerals are carbonates. Transmitted light, crossed polarizers, magnified 175x; photomicrograph by J. C. Zwaan.

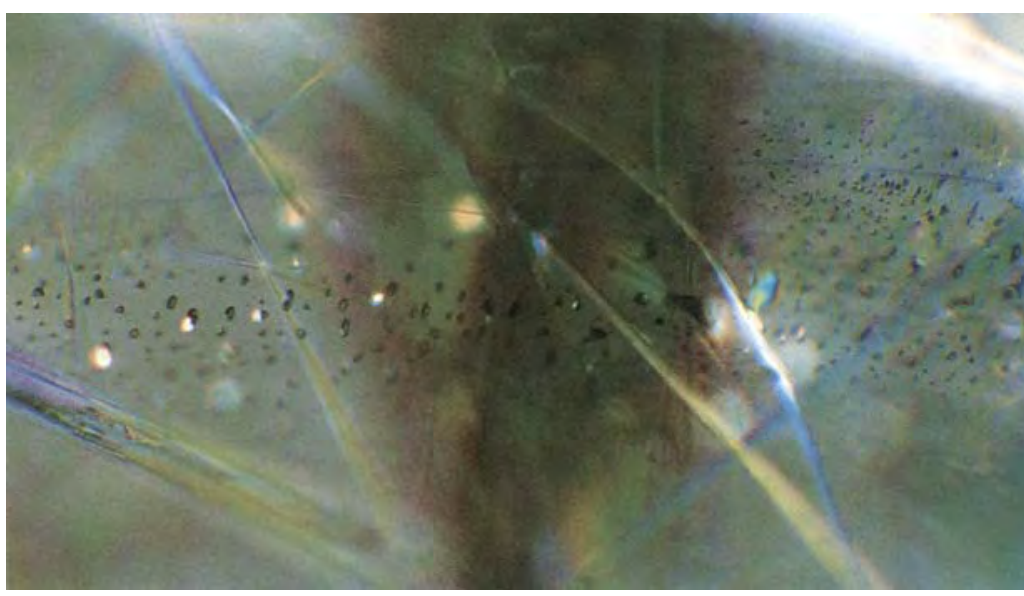


more chromium, but often no straightforward correlation between color intensity and chromium content could be found.

From these analyses, it can be seen that the chromium content is partly consistent with the values given by Gübelin (1958), Martin (1962), and Hänni (1982), but it can also be substantially higher.

The Sandawana emeralds also show low $\mathrm{Al}_{2} \mathrm{O}_{3}$ content but very high $\mathrm{MgO}$ and $\mathrm{Na}_{2} \mathrm{O}$ contents.

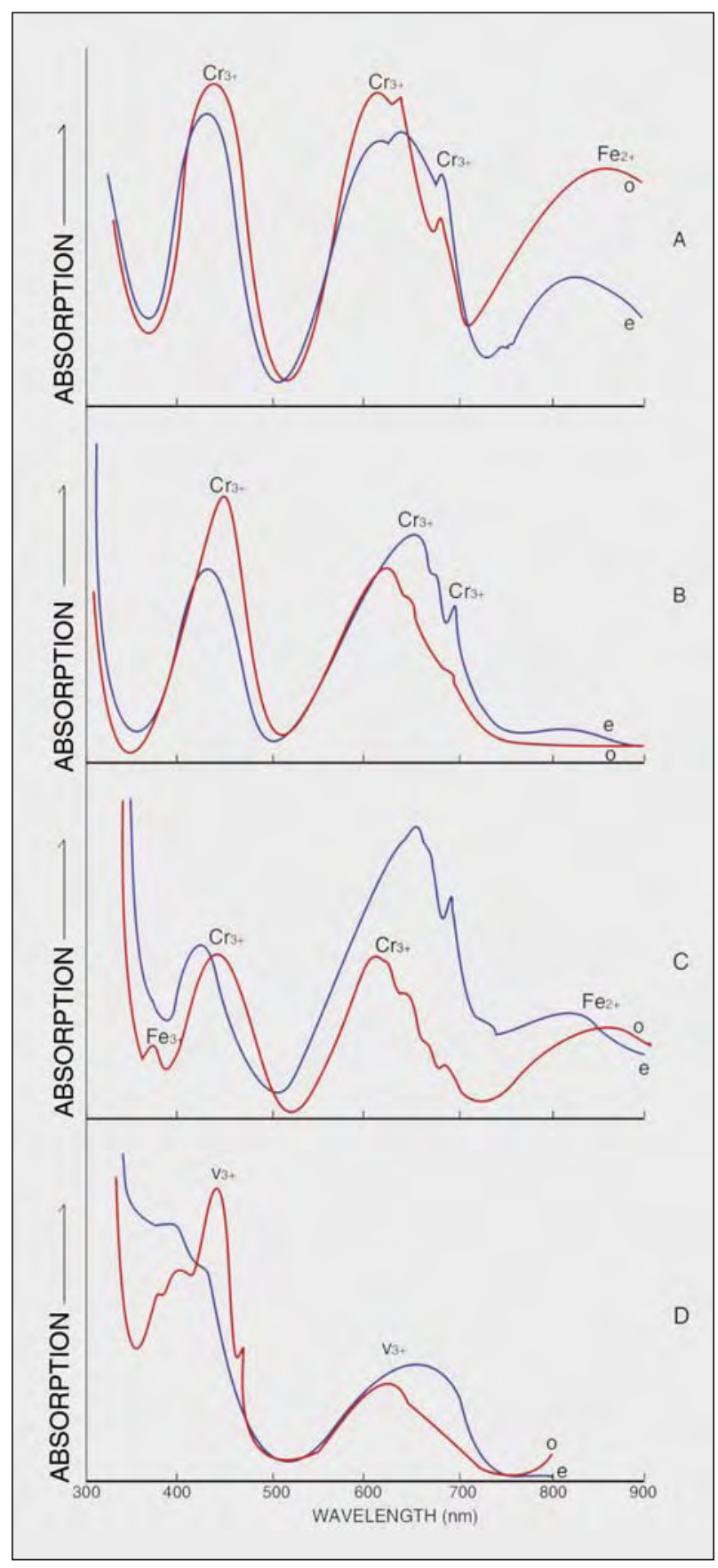

TABLE 2. Microprobe results of analyzed elements in four medium- to dark-green emeralds (range of average results) and one pale green beryl (the average for each element) from Sandawana. ${ }^{a}$

\begin{tabular}{lcc}
\hline Oxide & $\begin{array}{c}\text { Medium- to dark- } \\
\text { green emeralds } \\
\text { from the Zeus and } \\
\text { Orpheus mines (wt.\%) }\end{array}$ & $\begin{array}{c}\text { Pale green } \\
\text { beryl from the } \\
\text { Zeus mine (wt.\%) }\end{array}$ \\
\hline $\mathrm{SiO}_{2}$ & $62.6-63.2$ & 62.8 \\
$\mathrm{Al}_{2} \mathrm{O}_{3}$ & $13.0-13.7$ & 14.3 \\
$\mathrm{Cr}_{2} \mathrm{O}_{3}$ & $0.61-1.33$ & 0.16 \\
$\mathrm{~V}_{2} \mathrm{O}_{3}$ & $0.04-0.07$ & 0.04 \\
$\mathrm{FeO}$ & $0.45-0.82$ & 0.71 \\
$\mathrm{MgO}$ & $2.52-2.75$ & 2.38 \\
$\mathrm{Na}_{2} \mathrm{O}$ & $2.07-2.41$ & 2.30 \\
$\mathrm{~K}_{2} \mathrm{O}$ & $0.03-0.06$ & 0.06 \\
$\mathrm{Cs}_{2} \mathrm{O}$ & $0.06-0.10$ & 0.09 \\
$\mathrm{Rb}_{2} \mathrm{O}^{\mathrm{b}}$ & $\leq 0.04$ & bdl \\
$\mathrm{CaO}^{b}$ & $\leq 0.03$ & bdl \\
$\mathrm{TiO}_{2}^{\mathrm{b}}$ & $\leq 0.05$ & bdl \\
\hline
\end{tabular}

Comments: $\mathrm{BeO}, \mathrm{Li}_{2} \mathrm{O}$, and $\mathrm{H}_{2} \mathrm{O}$ cannot be analyzed with a microprobe. $\mathrm{MnO}, \mathrm{Sc}_{2} \mathrm{O}_{3}, \mathrm{~F}$, and $\mathrm{Cl}$ were below the detection limits. Total iron is reported as $\mathrm{FeO}$.

${ }^{b}$ Most of the analyses gave values equal to or below the detection limit (bdl).

Using Schwarz's empirical subdivision of low, medium, and high concentrations of elements in emerald (see, e.g., Schwarz, 1990), we would also conclude that the iron content is medium whereas the vanadium content is very low. Notable is the presence of cesium. As observed by Bakakin and Belov (1962), Cs is present typically in Li-rich beryl. Lithium cannot be analyzed by microprobe, but its presence is indicated by Gübelin (1958), Martin (1962), and Böhmke (1982), who reported $\mathrm{Li}_{2} \mathrm{O}$ values ranging from 0.10 to $0.15 \%$, respectively.

On the basis of structural refinements, Aurisicchio et al. (1988) proposed three types of beryls: "octahedral," in which substitutions in the $\mathrm{Al}$ octahedral site by $\mathrm{Fe}^{2+}$ and $\mathrm{Mg}^{2+}$ plus $\mathrm{Fe}^{3+}, \mathrm{Cr}^{3+}$,

Figure 29. The absorption spectrum recorded in Sandawana emeralds $(A)$ is comparable to that of Colombian emeralds (B), but the former has a strong absorption band in the near-infrared due to $\mathrm{Fe}^{2+}$. The spectrum of one Brazilian emerald (C) shows an additional peak in the violet due to $\mathrm{Fe}^{3+}$. The spectrum of a chrome-free emerald from Salininha, Brazil, which is colored by $\mathrm{V}^{3}$, is shown in (D). Spectra $B$ and $C$ are from Henn and Bank (1991); spectrum $D$ is from Wood and Nassau (1968). Red line = ordinary ray, blue line = extraordinary ray. 
$\mathrm{V}^{3+}, \mathrm{Mn}^{2+}$, and $\mathrm{Ti}^{4+}$ represent the main isomorphous replacement; "tetrahedral," in which the main substitution is $\mathrm{Li}$ in the Be tetrahedral site; and "normal," in which the two substitutions occur together, but to a limited extent. In this model, a compositional gap exists between beryls with octahedral and tetrahedral substitutions. According to this model, the analyzed emeralds from Sandawana would fall in the category of "octahedral" beryls.

\section{DISCUSSION}

Geology and Occurrence. The magnesium and chromium in Sandawana emeralds come from the greenstones into which the small pegmatites intruded. This is confirmed by the analysis of the pale-green beryl that was found in the pegmatite $1.25 \mathrm{~m}$ from the contact with the greenstones (table 2). It contains less $\mathrm{Mg}$ and $\mathrm{Cr}$ than the emeralds, which were found closer to the contact. Most of the komatiites that comprise the greenstones are Archean in age, and resemble in composition the Archean mantle. In this respect, one could suggest that emeralds from Sandawana owe their magnificent color (caused by chromium accompanied by a relatively low concentration of iron) to the composition of the very old greenstones in which they crystallized. The exact conditions under which the emeralds formed are still under investigation. The fact that most of the fluid inclusions have decrepitated suggests a long crystallization history, but shearing does not seem to be the most important factor. If it were, inclusions would be transposed in a series of secondary healed fractures, which is not commonly the case. Decrepitation of single inclusions is more likely related to episodes of sudden regional decompression (block uplift) after initial formation. However, more evidence is needed before any definite statements can be made on this subject.

Like Sandawana, many other emerald occurrences are located near the margin of cratonic areas, close to mobile belts (a long, relatively narrow crustal region of tectonic activity) or suture zones. For example, the Afghanistan emeralds are located in the Panjsher suture zone, which marks the closure of the Paleotethys Ocean; the Pakistan emeralds occur in the Indus suture zone, which is the collision margin between the Indo-Pakistan subcontinent and Asia; and the occurrence of emeralds in Russia is related to the collision of the European and Asian plates to form the Ural Mountains
(Kazmi and Snee, 1989). However, the Sandawana emerald occurrence is much older than the Asian or Russian deposits. This ancient suture zone may represent a collision between microcontinents, but the extent to which modern concepts of plate tectonics may be applied to this region is still under debate.

Identification. The higher R.I. values of Sandawana emeralds make them very easy to distinguish from their synthetic counterparts. The latter typically have lower refractive indices, roughly between 1.56 and 1.58 (see, e.g., Webster, 1983; Schrader, 1983; Liddicoat, 1989), although some Russian hydrothermal synthetic emeralds have shown R.I.'s up to 1.584 (see, e.g., Koivula et al., 1996).

On the basis of refractive index, birefringence, and specific gravity values (see, e.g., Gübelin, 1989; Schwarz, 1990, 1991; Schwarz and Henn, 1992), emeralds from Sandawana resemble emeralds from the Ural Mountains of Russia, the Habachtal region of Austria, the Santa Terezinha de Goiás deposits of Brazil, certain mines in Pakistan, and the Mananjary region in Madagascar. From table 3, it can be seen that emeralds from most of these other localities show greater variation in properties than the Sandawana stones. Also, most emeralds from the Ural Mountains and from the Mananjary region have lower values than those recorded for the Sandawana stones.

A comparison of inclusions reveals that emeralds from the Swat and Makhad mines in Pakistan do not contain any amphibole fibers and needles but frequently show black chromite and many twophase (liquid-gas) and three-phase (liquid-gas-solid) inclusions (Gübelin, 1989); thus, they look quite different from Sandawana emeralds. Emeralds from the Charbagh and Khaltaro mines in Pakistan (not mentioned in table 3 because most of the stones examined came from the Swat mines [the largest mines] and Makhad, and can be considered most representative of Pakistan emeralds) may contain brownish green to black actinolite rods, but certainly not thin fibers of amphibole; they also show slightly lower specific gravities and refractive indices (Gübelin, 1989).

Emeralds from the Ural Mountains may contain actinolite rods that closely resemble the longprismatic actinolite and cummingtonite crystals observed in Sandawana emeralds. However, the thin and often curved fibers seen in Sandawana emeralds have not been reported in Uralian emeralds; in the latter, phlogopite is frequently present 


\begin{tabular}{|c|c|c|c|c|}
\hline \multirow[t]{2}{*}{ Locality } & \multicolumn{2}{|c|}{ Refractive indices } & \multirow[t]{2}{*}{ Birefringence } & \multirow{2}{*}{$\begin{array}{l}\text { Specific } \\
\text { gravity }\end{array}$} \\
\hline & $\mathrm{n}_{\varepsilon}$ & $\mathrm{n}_{\omega}$ & & \\
\hline Sandawana, Zimbabwe & $1.584-1.587$ & $1.590-1.594$ & $0.006-0.007$ & $2.74-2.77$ \\
\hline Swat Mines, Pakistan & $1.578-1.591$ & $1.584-1.600$ & $0.006-0.009$ & $2.70-2.78$ \\
\hline Makhad, Pakistan & $1.579-1.587$ & $1.586-1.595$ & $0.007-0.008$ & $2.74-2.76$ \\
\hline Ural Mountains, Russia & $1.575-1.584$ & $1.581-1.591$ & 0.007 & $2.72-2.75$ \\
\hline Habachtal, Austria & $1.574-1.590$ & $1.582-1.597$ & $0.005-0.007$ & $2.70-2.77$ \\
\hline Santa Terezinha de Goiás, Brazil & $1.584-1.593$ & $1.592-1.600$ & $0.006-0.010$ & $2.75-2.77$ \\
\hline Mananjary Region, Madagascar & $1.580-1.585$ & $1.588-1.591$ & $0.006-0.009$ & $2.68-2.73$ \\
\hline
\end{tabular}

as rounded platelets or as large, elongated tabular crystals (Schmetzer et al., 1991; Gübelin and Koivula, 1992). Although phlogopite has been found in emeralds from Sandawana, it is uncommon. Like the Uralian emeralds, the emeralds from Habachtal contain actinolite rods and phlogopite platelets, but --like the Sandawana emeralds--the Austrian stones also have apatite crystals (Gübelin and Koivula, 1992). However, these emeralds normally show an inhomogeneous-"patchy" - color distribution (Morteani and Grundmann, 1977) that has not been seen in Sandawana emeralds.

Although amphibole has been identified in emeralds from Santa Terezinha, Brazil, these emeralds are characterized by abundant opaque inclusions such as black spinel (as small octahedra and larger irregular grains), hematite, rutile, and pyrite. They also contain various pale-brown to colorless carbonates, which are present as irregular grains, aggregates, and fillings of fractures, but also as rhombohedra (Schwarz, 1990). By contrast, opaque inclusions of distinguishable size are rare in Sandawana emeralds, so separation from these Brazilian emeralds should be relatively easy.

Inclusions in emeralds from Madagascar may look very similar to those found in Sandawana emeralds, because long-prismatic amphibole rods are frequently found (Schwarz and Henn, 1992; Schwarz, 1994) as well as fibrous aggregates of talc (Schwarz, 1994), which may resemble the amphibole fibers present in Sandawana emeralds. Feldspar crystals and carbonates have also been identified, although feldspar is less common in Madagascar stones (Schwarz, 1994). Hänni and Klein (1982) identified apatite, too. However, in many Mananjary emeralds, transparent, somewhat rounded or "pseudo-hexagonal" mica (usually biotite/phlogopite) is the most common inclusion (Hänni and Klein, 1982; Schwarz and Henn, 1992; Schwarz, 1994). Fluid inclusions were observed in most Mananjary emeralds; the larger inclusions are often somewhat rectangular-shaped negative crystals filled with gas and liquid (Hänni and Klein, 1982; Schwarz, 1994), but three-phase (solid-liquid-gas) inclusions may also occur (Schwarz and Henn, 1992). As mentioned above, neither mica nor fluid inclusions are frequently found in Sandawana emeralds.

The chemistry of emeralds from the mentioned localities provides additional evidence (table 4). The chromium content is distinctly lower for emeralds from the Ural Mountains, Habachtal, and the Mananjary region. For the Uralian emeralds, this was confirmed by Laskovenkov and Zhernakov (1995), who gave typical chromium contents of $0.15-0.25 \mathrm{wt} . \%$, with the content in some stones as high as 0.38 wt. \%. In emeralds from Santa Terezinha, the chromium content can be very low, but also very high. However, the sodium content is lower-and, in most cases, the iron content is higher-than in emeralds from Sandawana.

All of the Sandawana emeralds we tested showed high magnesium and sodium contents, with little variation from stone to stone as well as within a stone. The average compositions can thus be compared with compositions of emeralds from other localities with the help of, for instance, $\mathrm{Na}_{2} \mathrm{O} / \mathrm{MgO}$ and $\mathrm{Na}_{2} \mathrm{O} / \mathrm{Al}_{2} \mathrm{O}_{3}$ variation diagrams (figure 30). In both diagrams, the representative points for Sandawana emeralds show distinctly high contents of both sodium and magnesium. Only some emeralds from Habachtal and the Mananjary region, and emeralds from the Swat and Makhad mines, Pakistan, show comparable contents and ratios. As stated above, this similarity poses no problem for Habachtal and Mananjary emeralds, because these contain less chromium. Emeralds 


\begin{tabular}{|c|c|c|c|c|c|c|c|}
\hline Oxide & $\begin{array}{l}\text { Sandawana, } \\
\text { Zimbabwe }\end{array}$ & $\begin{array}{l}\text { Swat mines, } \\
\text { Pakistan }\end{array}$ & $\begin{array}{l}\text { Makhad, } \\
\text { Pakistan }\end{array}$ & $\begin{array}{l}\text { Ural } \\
\text { Mountains, } \\
\text { Russia }\end{array}$ & $\begin{array}{l}\text { Habachtal, } \\
\text { Austria }\end{array}$ & $\begin{array}{c}\text { Santa } \\
\text { Terezinha, } \\
\text { Brazil }\end{array}$ & $\begin{array}{l}\text { Mananjary } \\
\text { Region, } \\
\text { Madagascar }\end{array}$ \\
\hline $\mathrm{SiO}_{2}$ & $62.6-63.2$ & $62.7-62.8$ & $62.2-62.9$ & $64.6-66.9$ & $64.6-66.1$ & $63.8-66.5$ & $63.3-65.0$ \\
\hline $\mathrm{Al}_{2} \mathrm{O}_{3}$ & $13.0-13.7$ & $13.1-14.2$ & $13.5-14.2$ & $14.2-18.3$ & $13.3-14.5$ & $12.2-14.3$ & $12.8-14.6$ \\
\hline $\mathrm{Cr}_{2} \mathrm{O}_{3}$ & $0.61-1.33$ & $0.39-1.17$ & $0.23-1.26$ & $0.01-\quad 0.50$ & $0.01-0.44$ & $0.06-1.54$ & $0.08-0.34$ \\
\hline $\mathrm{V}_{2} \mathrm{O}_{3}$ & $0.04-0.07$ & $0.01-0.06$ & $0.04-0.06$ & $\leq 0.04$ & $\leq 0.04$ & $\leq 0.08$ & $\leq 0.03$ \\
\hline $\begin{array}{l}\mathrm{FeO} \\
\mathrm{MnO}\end{array}$ & $\begin{array}{c}0.45-\quad 0.82 \\
\text { n.d. }\end{array}$ & $\begin{array}{c}0.52-\quad 0.91 \\
\text { n.d. }\end{array}$ & $\begin{array}{c}0.44-\quad 0.67 \\
\text { n.d. }\end{array}$ & $\begin{array}{c}0.10-1.16 \\
\leq 0.03\end{array}$ & $\begin{array}{c}0.61-1.87 \\
\leq 0.05\end{array}$ & $\begin{array}{c}0.77-1.82 \\
\leq 0.02\end{array}$ & 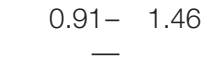 \\
\hline $\mathrm{MgO}$ & $2.52-\quad 2.75$ & $2.46-2.50$ & $2.37-2.68$ & $0.29-\quad 2.23$ & $2.33-2.92$ & $2.48-3.09$ & $1.71-3.00$ \\
\hline $\mathrm{Na}_{2} \mathrm{O}$ & $2.07-2.41$ & $2.06-2.11$ & $1.64-\quad 2.05$ & $0.61-\quad 1.72$ & $1.54-2.24$ & $1.46-1.73$ & $1.28-2.16$ \\
\hline $\mathrm{K}_{2} \mathrm{O}$ & $0.03-0.06$ & - & $\leq 0.02$ & $\leq 0.07$ & $0.01-0.10$ & $\leq 0.03$ & $0.05-\quad 0.21$ \\
\hline $\mathrm{Cs}_{2} \mathrm{O}$ & $0.06-\quad 0.10$ & - & - & - & - & - & - \\
\hline $\mathrm{Rb}_{2} \mathrm{O}$ & $\leq 0.04$ & - & - & - & - & - & - \\
\hline $\mathrm{CaO}$ & $\leq 0.03$ & n.d. & n.d. & $\leq 0.03$ & $0.02-0.04$ & - & - \\
\hline $\mathrm{TiO}_{2}$ & $\leq 0.05$ & n.d. & $0.01-0.02$ & $\leq 0.05$ & $\leq 0.03$ & - & n.d. \\
\hline $\mathrm{Sc}_{2} \mathrm{O}_{3}$ & n.d. & - & $0.17-0.19$ & - & - & - & - \\
\hline $\mathrm{Mo}_{2} \mathrm{O}_{3}$ & n.d. & - & - & - & $\leq 0.04$ & - & - \\
\hline
\end{tabular}

from Pakistan may be readily distinguished by their different inclusion scenery. Note that emeralds from the Makhad mine were found to have appreciable scandium (table 4), which was not detected in the Sandawana emeralds.
Because of the relatively constant properties of Sandawana emeralds, these stones can be readily separated from emeralds from other localities on the basis of a combination of physical properties, inclusions, and chemistry.

Figure 30. These variation diagrams of $\mathrm{Na}_{2} \mathrm{O}$ versus $\mathrm{MgO}$ (left) and $\mathrm{Na}_{2} \mathrm{O}$ versus $\mathrm{Al}_{2} \mathrm{O}_{3}$ (right) in emeralds with comparable physical properties illustrate that the Sandawana emeralds can be distinguished by their high sodium content, with overlapping values for emeralds from Austria and Pakistan. Urals and Habachtal data from Schwarz (1991); Santa Terezinha data from Schwarz (1990); Pakistan data from Hammarstrom (1989); Madagascar data from Hänni and Klein (1982) and Schwarz and Henn (1992).
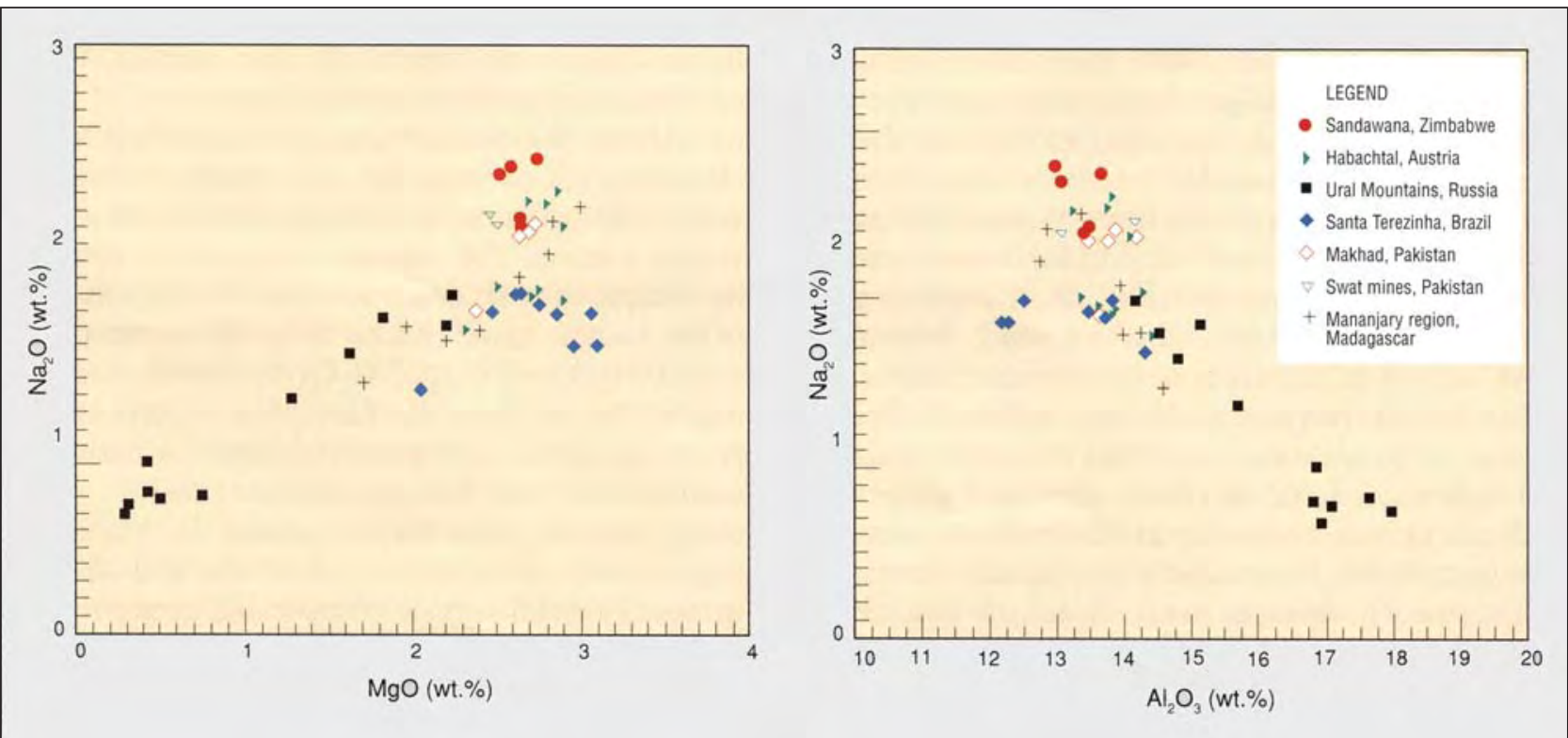


\section{CONCLUSION}

First discovered in 1956, Sandawana emeralds have become well known for their splendid vivid green color and the typically small size $(0.05-0.25 \mathrm{ct})$ of the polished stones (figure 31). Since Sandawana Mines Pvt. (Ltd.) assumed management of the mines in 1993, more stones up to $1.50 \mathrm{ct}$ have been produced. Stones above $1.50 \mathrm{ct}$ are still rare.

The emeralds probably formed during a major deformation event around 2.6 billion years ago, when small beryllium- and lithium-bearing pegmatites intruded into chromium- and magnesiumrich greenstones, which incorporated the elements necessary for emerald to crystallize.

Sandawana emeralds show relatively constant physical properties, with high refractive indices and specific gravities compared to emeralds from other localities. Also unlike emeralds from many other localities, they are not characterized by fluid inclusions but rather by laths and fibers of amphibole, both actinolite and cummingtonite (previously reported to have been tremolite). Other common inclusions are albite and apatite. The relative absence of fluid inclusions is due to decrepitation of these inclusions during geologic history. Nevertheless, remnants of fluid-inclusion trails are common features.

The chemistry is characterized by very high contents of chromium, sodium, and magnesium. Chromium contents in some samples were substantially higher than in specimens reported from other deposits.

Although most emeralds from other localities with physical properties that overlap those for Sandawana emeralds also show solid inclusions, including actinolite rods (Russia, Brazil, Austria, Madagascar), it is relatively easy to distinguish emeralds from Sandawana by their internal characteristics. Amphibole fibers, in particular, are seldom seen in stones from other localities, whereas they are abundant in Sandawana stones. Phlogopite and some opaque inclusions, though identified in Sandawana emeralds, are much less common than in emeralds from the other localities. The chem-

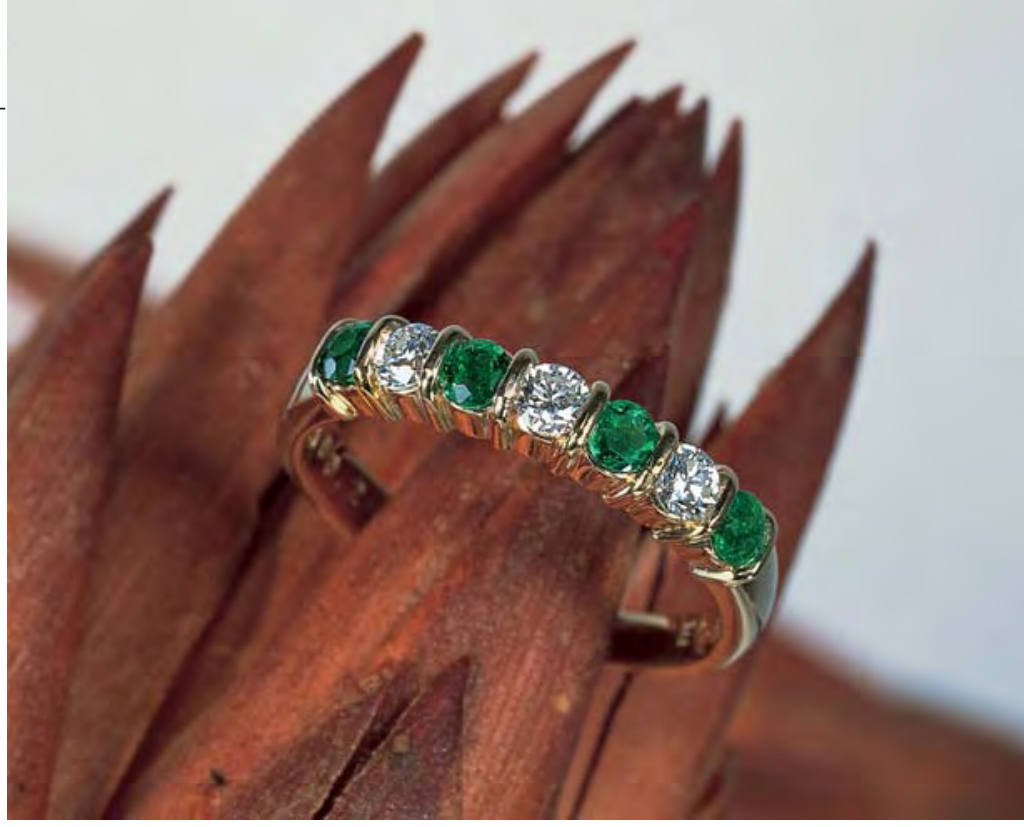

Figure 31. Sandawana emeralds are popular in rings because of their saturated color in small sizes. The four emeralds in this anniversary ring weigh a total of $0.32 \mathrm{ct}$. Courtesy of Suwa 4 Son, Tokyo, Japan.

istry of emeralds from Pakistan is closest to that recorded for Sandawana stones, but emeralds from the two localities can easily be distinguished by their completely different internal characteristics.

Acknowledgments: The authors thank Prof. Dr. J. L. R. Touret for critically reading the manuscript and Ernst A. I. Burke and Willem I. Lustenhouwer for helping with Raman spectroscopy and microprobe analyses. Facilities for Raman spectroscopy and electron microprobe analyses were provided by the Free University of Amsterdam and by NWO, the Netherlands Organization for Scientific Research. Most of the gem material tested was kindly provided by Sandawana Mines (Pvt.) Ltd. Mr. D. Bode of Bodes et Bode, The Netherlands, also kindly loaned some polished stones for testing.

Dirk van der Marel, technician at the National Museum of Natural History, is thanked for his assistance with all the paperwork.

The financial support of the Foundation Stichting Dr. Schürmannfonds is gratefully acknowledged.

\section{REFERENCES}

Anderson S.M. (1976) A note on the occurrence of emerald at Mayfield Farm, Fort Victoria, Rhodesia. Journal of Gemmology, Vol. 15, No. 2, pp. 80-82.

Anderson S.M. (1978) Notes on the occurrence and mineralogy of emeralds in Rhodesia. Journal of Gemmology, Vol. 16, No. 3, pp. 177-185.

Aurisicchio C., Fioravanti G., Grubessi O., Zanazzi P.F. (1988 Reappraisal of the crystal chemistry of beryl. American Mineralogist, Vol. 73, pp. 826-837.

Bakakin V.V., Belov N.V. (1962) Crystal chemistry of beryl. Geokhimiya, Vol. 5, pp. 420-433.

Böhmke F.C. (1966) The geology of the Sandawana Mines. 
Internal report, Sandawana Mines, Harare, Zimbabwe.

Böhmke F.C. (1982) Emeralds at Sandawana. In Gemstones, Report of the Sixth Annual Commodity Meeting, Institution of Mining and Metallurgy (IMM), London, United Kingdom, pp. A110-A122.

Bosshart G. (1991) Emeralds from Colombia (Part 2). Journal of Gemmology, Vol. 22, No. 7, pp. 409-425.

Fedo C.M., Eriksson A., Blenkinsop T.G. (1995) Geologic history of the Archean Buhwa greenstone belt and surrounding granite-gneiss terrane, Zimbabwe, with implications for the evolution of the Limpopo belt. Canadian Journal of Earth Sciences, Vol. 32, pp. 1977-1990.

Fedo C.M., Eriksson K.A. (1996) Stratigraphic framework of the -3.0 Ga Buhwa Greenstone Belt: A unique stable-shelf succession in the Zimbabwe Archean craton. Precambrian Research, Vol. 77, pp. 161-178.

Fleischer J.A., Mandarino J.A. (1995) Glossary of Mineral Species 1995. The Mineralogical Record Inc., Tucson, Arizona.

Gübelin E.J. (1958) Emeralds from Sandawana. Journal of Gemmology, Vol. 6, No. 8, pp. 340-354.

Gübelin E.J. (1989) Gemological characteristics of Pakistani emeralds. In H. Kazmi and L. W. Snee, Eds., Emeralds of Pakistan: Geology, Gemology and Genesis, Van Nostrand Reinhold, New York, pp. 75-92.

Gübelin E.J., Koivula J.I. (1992) Photoatlas of Inclusions in Gemstones, 2nd rev. ed. ABC Edition, Zurich, Switzerland.

Hammerstrom J.M. (1989) Mineral chemistry of emeralds and some associated minerals from Pakistan and Afghanistan: An electron microprobe study. In H. Kazmi and L. W. Snee, Eds., Emeralds of Pakistan: Geology, Gemology and Genesis, Van Nostrand Reinhold, New York, pp. 125-150.

Hänni H.A. (1982) A contribution to the separability of natural and synthetic emeralds. Journal of Gemmology, Vol. 18, No. 2, pp. 138-144.

Hänni H.A., Kiefert L., Chalain J.P. (1997) A Raman microscope in the gemmological laboratory: First experiences of application. Journal of Gemmology, Vol. 25, No. 6, pp. 394-406.

Hänni H.A., Klein H.H. (1982) Ein Smaragdvorkommen in Madagaskar. Zeitschrift der Deutschen Gemmologischen Gesellschaft, Vol. 31, No.1/2, pp. 71-77.

Henn U., Bank H. (1991) Außergewöhnliche Smaragde aus Nigeria. Zeitschrift der Deutschen Gemmologischen Gesellschaft, Vol. 40, No. 4, pp. 181-187.

Kanis J., Arps C.E.S., Zwaan P.C. (1991) 'Machingwe': A new emerald deposit in Zimbabwe. Journal of Gemmology, Vol. 22, No. 5, pp. 264-272.

Kazmi A.H., Snee L.W. (1989) Geology of the world emerald deposits: A brief review. In H. Kazmi and L. W. Snee, Eds., Emeralds of Pakistan: Geology, Gemology and Genesis, Van Nostrand Reinhold, New York, pp. 165-228.

Koivula J.I., Kammerling R.C., DeGhionno D., Reinitz I., Fritsch E., Johnson M.L. (1996) Gemological investigation of a new type of Russian hydrothermal synthetic emerald. Gems $\uplus$ Gemology, Vol. 32, No. 1, pp. 32-39.

Laskovenkov A.F., Zhernakov V.I. (1995) An update on the Ural emerald mines. Gems \& Gemology, Vol. 31, No. 2, pp. 106-113.

Leake B.E. (1978) Nomenclature of amphiboles. American Mineralogist, Vol. 63, pp. 1023-1052.

Liddicoat R.T. (1989) Handbook of Gem Identification, 12th ed., 2nd rev. printing. Gemological Institute of America, Santa Monica, CA.

Lind Th., Henn U., Bank H. (1986) Smaragde von Sta. Terezinha de Goias, Brasilien, mit relativ hoher Lichtbrechung. Zeitschrift der Deutschen Gemmologischen Gesellschaft, Vol. 35, No. 4, pp. 186-187.
Martin H.J. (1962) Some observations on Southern Rhodesian emeralds and chrysoberyl. Chamber of Mines Journal, Vol. 4, No. 10 , pp. 34-38.

Mennell F.P. (1906) Somabula diamond field of Rhodesia. Geological Magazine, Vol. 3, No. 508, pp. 459-462.

Metson N.A., Taylor A.M. (1977) Observations on some Rhodesian emerald occurrences. Journal of Gemmology, Vol. 15 , No. 8, pp. 422-434.

Mkweli S., Kamber B., Berger M. (1995) Westward continuation of the craton-Limpopo belt tectonic break in Zimbabwe and new age constraints on the timing of the thrusting. Journal of the Geological Society, London, Vol. 152, pp. 77-83.

Morteani G., Grundmann G. (1977) The emerald porphyroblasts in the penninic rocks of the central Tauern Window. Neues Jahrbuch für Mineralogie Mitteilungen, Vol. 11, pp. 509-516.

Mumme I. (1982) The Emerald. Mumme Publications, Port Hacking, N.S.W., Australia.

Pinet M., Smith D., Lasnier B. (1992). Utilité de la microsonde Raman pour l'identification non destructive des gemmes. In La Microsonde Raman en Gemmologie-Revue de Gemmologie a.f.g., No. outside of series, pp. 11-61.

Robertson I.D.M. (1973) Potash granites of the southern edge of the Rhodesian craton and the northern granulite zone of the Limpopo mobile belt. In Lister L.A., Symposium on Granites, Gneisses and Related Rocks, Geological Society of South Africa Special Publication 3, Salisbury, pp. 265-276.

Rollinson H., Blenkinsop T. (1995) The magmatic, metamorphic and tectonic evolution of the Northern Marginal Zone of the Limpopo belt in Zimbabwe. Journal of the Geological Society, London, Vol. 152, pp. 65-75.

Schmetzer K., Berdesinski W., Bank H. (1974) Über die Mineralart Beryll, ihre Farben und Absorptionsspektren. Zeitschrift der Deutschen Gemmologischen Gesellschaft, Vol. 23, No. 1, pp. 5-39.

Schmetzer K., Bernhardt H., Biehler R. (1991) Emeralds from the Ural Mountains, USSR. Gems Æ Gemology, Vol. 27, No. 2, pp. 86-99.

Schrader H.W. (1983) Contributions to the study of the distinction of natural and synthetic emeralds. Journal of Gemmology, Vol. 18, No. 6, pp. 530-543.

Schwarz D. (1990) Die brasilianischen Smaragde und ihre Vorkommen: Santa Terezinha de Goiás/Go. Zeitschrift der Deutschen Gemmologischen Gesellschaft, Vol. 39, No. 1, pp. $13-44$.

Schwarz D. (1991). Die chemischen Eigenschaften der Smaragde III. Habachtal/Österreich und Uralgebirge/UdSSR. Zeitschrift der Deutschen Gemmologischen Gesellschaft, Vol. 40, No. 2/3, pp. 103-143.

Schwarz D. (1994) Emeralds from the Mananjary Region, Madagascar: Internal features. Gems ↔) Gemology, Vol. 30, No. 2, pp. 88-101.

Schwarz D., Henn U. (1992) Emeralds from Madagascar. Journal of Gemmology, Vol. 23, No. 3, pp. 140-149.

Summers R. (1969) Ancient Mining in Rhodesia. Trustees of the National Museum of Rhodesia, Mardon Printers, Salisbury.

Wagner P.A. (1914) The Diamond Fields of Southern Africa. Reprinted 1971, Struik (Pty) Ltd., Cape Town, South Africa.

Webster R. (1983) Gems: Their Sources, Descriptions and Identification, 4th ed. Rev. by B. W. Anderson, ButterworthHeinemann, London.

Wood D.L., Nassau K. (1968). The characterization of beryl and emerald by visible and infrared absorption spectroscopy. American Mineralogist, Vol. 53, pp. 777-799.

Worst B.G. (1956) The Geology of the Country between Belingwe and West Nicholson. Southern Rhodesia Geological Survey, Bulletin No. 43. 